\title{
Racial prejudice and social values: how I perceive others and myself
}

\author{
Samuel Lincoln Bezerra Lins - Universidade do Porto, Porto, Portugal \\ Tiago Jessé Souza de Lima - Universidade de Fortaleza, Fortaleza, Brasil \\ Luana Elayne Cunha de Souza - Universidade de Fortaleza, Fortaleza, Brasil \\ Aline Lima-Nunes - Universidade Federal de Campina Grande, Campina Grande, Brasil \\ Leoncio Camino - Universidade Federal da Paraíba, João Pessoa, Brasil
}

\begin{abstract}
The process of attribution values to some groups can be used as a resource for determining differences between ingroup and outgroup, what may lead to discriminatory behavior against the outgroup. In this sense, the present study sought to determine whether individuals perceive dissimilarities between the values attibuted to themselves, to white and to black people, and if these dissimilarities can follow a prejudice-based logic, expressing subtle racial prejudice. Study $1(n=220)$ aimed to rank the values in terms of socio-economic progress, identifying values that are representative of developed and underdeveloped countries. Study $2(n=420)$ evaluated whether the values attibuted to themselves, to the black and to the white are different and this difference follows a prejudice-based. Overall, results showed a tendency towards the association of third world values such as collectivism to blacks, and first world values such as individualism to whites.

Keywords: social values; racism; attribution; intergroup relations.
\end{abstract}

\section{Preconceito racial e valores sociais: como percebo a mim e ao outro}

\section{Resumo}

O processo de atribuição de valores a alguns grupos pode ser utilizado como um recurso para demarcar diferenças entre endogrupo e exogrupo, o que pode levar a comportamentos discriminatórios contra o exogrupo. Nesse sentido, o presente trabalho busca avaliar se os indivíduos percebem dissimilaridades entre os valores atribuídos a si mesmos, aos brancos e aos negros, e se essas dissimilaridades podem seguir uma lógica preconceituosa, expressando de forma sutil o preconceito racial. O Estudo 1 $(n=220)$ objetivou hierarquizar os valores em termos de progresso socioeconômico, identificando aqueles valores representativos de países desenvolvidos e subdesenvolvidos. O Estudo $2(n=420)$ avaliou se os valores atribuídos a si mesmos, a negros e a brancos são diferentes e se essa diferença segue uma lógica preconceituosa. De modo geral, os resultados mostraram uma tendência na associação de valores de terceiro mundo, coletivistas, aos negros e de valores de primeiro mundo, individualistas, aos brancos.

Palavras-chave: valores sociais, racismo, atribuição, relações intergrupais

Prejuicio racial y valores sociales: como me percibo y percibo a mi semejante

\begin{abstract}
Resumen
El proceso de atribución de valores a algunos grupos puede ser utilizado como un recurso para señalar diferencias entre endogrupo y exogrupo, lo que puede llevar a comportamientos discriminatorios contra el exogrupo. En este sentido, este trabajo busca evaluar si los individuos perciben disimilitudes entre los valores atribuidos a sí mismos, a los blancos y a los negros, y si esas disimilitudes pueden seguir una lógica prejuiciosa, expresando de forma sutil el prejuicio racial. El estudio 1 ( $\mathrm{n}=220)$ tuvo como objetivo jerarquizar los valores en términos de progreso socioeconómico, identificando aquellos valores representativos de países desarrollados y subdesarrollados. El Estudio $2(\mathrm{n}=420)$ evaluó si los valores atribuidos a sí mismos, a blancos y a negros son diferentes y si esa diferencia sigue una lógica prejuiciosa. En general, los resultados muestran una tendencia en la asociación de valores del tercer mundo, colectivistas a los negros, y de valores del primer mundo, individualistas, a los blancos. Palabras-clave: valores sociales; racismo; atribución; relaciones intergrupales.
\end{abstract}

Since the earliest expressions of racial prejudice documented, there is a pattern of derogation, attempting to negatively differentiate the black, in explicit manner, as a "race" that is not intelligent, but lazy and misleading in its nature. However, the forms of prejudice are influenced, and even defined by the salient social norms in the context (McDonald \& Crandall, 2015). Due to significant changes in the rules and legislation of many countries that now state racism as a crime, the open racism (classic, based on explanations of phenotypic differences between the groups to justify psychological and cultural differences) declined and gave space to forms of more subtle and veiled expressions of racism.

Different subtle forms of expression of prejudice and racism were classified according to their own peculiarities of their expression contexts and victimized groups, such as subtle prejudice (Pettigrew \& Meertens, 
1995), symbolic racism (Kinder \& Sears, 1981), modern racism (McConahay, 1986) and ambivalent racism (Katz \& Hass, 1988). These subtle expressions of racism can occur, for example, through the denial of positive attributes to a group (Camino, Silva, Machado \& Pereira, 2001), through the defense of the values and the culture of the dominant group (Pettigrew \& Meertens, 1995), by avoidance of close contact (Gaertner \& Dovidio, 1986), and the denial of rights based on meritocratic arguments (Sears \& Kinder, 1971).

Common to these theories, and the classical theories about prejudice, is the notion that ingroup values can lead to a rejection of the outgroup (Allport, 1954; Gaertner \& Dovidio, 1986; Kinder \& Sears, 1981; Katz $\&$ Hass, 1988). In general, the abovementioned theories assume that the world is interpreted in terms of ingroup values, so that the outgroups that violate these values are rejected or perceived as negligible (Biernat \& Vescio, 2004). In fact, some researches have shown that the perception of dissimilarities between the ingroup and outgroup values lead to prejudice-based attitudes (Greenhalgh \& Watt, 2015; Ramsay, Pang, Shen, \& Rowatt, 2013).

However, the influence of the values in prejudice and discrimination can go beyond the perception of dissimilarities between the groups. The process of attribute certain values to some groups can be used as a resource to mark fundamental differences between the ingroup and the outgroup, constituting as a prominent factor in understanding the persistence of racism (Camino et al., 2001). However, this hypothesis has been scarcely tested in the literature (Bain, Park, Kwok, \& Haslam, 2009). In this sense, the present study seeks to analyse whether individuals perceive dissimilarities between the values attibuted to themselves, to white and black, and the possibility of these dissimilarities can follow a prejudice-based logic, expressing subtle racial prejudice.

\section{Social values}

In social psychology, the explanations given to values are mostly of intra-individual nature. That is, the sources of values are, above all, the individual needs (Rokeach, 1973) that, when distributed hierarchically, organize the beliefs of individuals in a system of values. Models of values proposed by Rokeach (1973), Schwartz (1992) and Gouveia, Milfont and Guerra (2014) fit in this definition. Another perspective understands the values as implicitly or explicitly shared abstract ideas about what would be right, good and desirable in a society or culture. In this perspective are inserted models that explain the values at cultural level, such as those proposed by Schwartz (2006), Inglehart (1977) and Hofstede (1980).

Taking into account the need for links between levels of explanation of psychosocial phenomena in Social Psychology (Doise, 1982), a new theory, the Societal Approach of Values (Pereira, Camino, \& Costa, 2004) has been proposed in order to integrate the psychological perspective of motivational types of values (Schwartz, 1992) with the sociological perspective of materialistic and post-materialistic values (Inglehart, 1991). For this approach, values are defined as socially elaborated knowledge structures that (a) summarize the elements of a widely shared symbolic system, (b) express the ideological conflicts that make up this system, (c) guide the selection of behaviors and (d) reflect the sociocultural context and the social identities of individuals (Estramiana, Pereira, Monter, \& Zlobina, 2014; Fernandes, Costa, Camino, \& Mendoza, 2007).

The societal approach proposes that the values represent various ideological tendencies with which social groups are identified. Such tendencies are organized into four systems, with its own content: materialistic, post-materialistic, religious and hedonistic (Pereira et al., 2004; Pereira, Camino, \& Costa, 2005). The material system is the ideology of accumulation of wealth and social status. The groups that identify themselves with this system are more focused on getting material resources, quest for power, while they cherish and value the authority (Pereira et al., 2004, 2005). The materialistic system is represented by the values wealth, authority, status and profit.

The post-materialistic system represents the ideologies of social well-being, self-realization and knowledge (Pereira et al., 2004, 2005). This system is divided into three subtypes: social well-being, individual well-being, and professional well-being. Social well-being represents the identification with the welfare of society and is associated with broader issues of human rights and citizenship; it is represented by the values: social justice, freedom, equality and fraternity. The individual well-being represents the identification with the more abstract personal achievements and subjective well-being, and is made up by the values: joy, love, comfort and self-fulfillment. Professional wellbeing represents the self-realization in the professional context, demonstrating responsibility and competence; it is composed of the values: professional achievement, hard work, responsibility and competence. 
The religious system is the ideology of obedience to religious rules, covering the following values: obedience to the laws of God, religiosity, soul salvation and fear of God. Finally, the hedonistic system represents the pursuit of pleasure and excitement in life, and is also aimed at enhancement of sexuality (Pereira et al., 2004, 2005). The values that represent the hedonistic system are pleasure, an exciting life, sexuality and sensuality.

According to the societal approach, the aforementioned systems are organized in two dimensions. The first dimension is formed by the materialistic and post-materialism systems (Inglehart, 1977; Pereira et al., 2005). The second dimension contrasts the religious system to the hedonistic system. In fact, the religious and hedonistic systems may represent antagonistic interests (Schwartz, 1996; Pereira et al., 2005), as an opposition between the materialistic and postmaterialistic systems is also likely, since the values that make up then emerge in different socioeconomic conjunctures (Inglehart, 1977). However, systems of values are positively correlated with each other, indicating that the values are not structured in function of conflictive relationships, as stated Schwartz et al. (2012), but in function of their possible compatibilities (Pereira et al. 2004, 2005).

\section{Social values and racism}

For Rokeach (1973), differences in beliefs and values among social groups or cultures would be the basis for prejudice. Some studies have pointed out, for example, that individuals who admit greater difference in beliefs between ingroup and outgroup are the most prejudiced (Bain et al., 2009; Greenhalgh \& Watt, 2015; Esses, Veenvliet, Hodson, \& Mihic, 2008). Thus, discrimination against the outgroup would be influenced by the level of similarity perceived between the beliefs and values of the ingroup and the outgroup. According to Rokeach (1968), the role of perception of differences in cultural values on the construction of racist attitudes can be framed in a wider context of the analysis of systems of values and prejudices. These perceived differences, from a symbolic perspective, are worth invested, which directs to an appreciation of the ingroup, and consequently, to a depreciation of the outgroup (Tajfel, 1982). This phenomenon, defined as "motivation for positive distinctiveness" is the key element in the theory of social identity (Tajfel, 1982). It is this motivation that produces the various forms of intergroup bias, such as prejudice and intergroup discrimination.
As previously mentioned, the notion that values can lead to rejection of the outgroup is prominent in many contemporary theories on racism (Bienart \& Vescio, 2004). The theories on modern and symbolic racism, for example, suggest that racism is largely based on the perception that black people violate the values of individualism, the work ethic, the Protestant ethic, obedience and discipline (Kinder \& Sears, 1991; McConhahay \& Hough, 1976). In ambivalent racism, for example, pro- and anti-black attitudes are derived from two types of values: attitudes against blacks are based on the values of the Protestant ethic, while pro-black attitudes are based on the values of humanitarianism/ egalitarianism (Katz \& Hass, 1988). In the theory of aversive racism, what distinguishes the aversive racists from the flagrant racists is that the aversive have a selfimage of egalitarian and are, therefore, more likely to act on behalf of blacks in normative contexts where the value of equality is emphasized.

Although the aforementioned studies indicate that the prejudice is related to the perception of difference in the ingroup and outgroup values, few studies have tested whether the prejudice motivates the attribution of values to the outgroup in order to devalue it. Camino et al. (2001) argue that the process of attribution values to social groups can be used as a differentiating feature between the in- and outgroup. Leach, Ellemers and Barreto (2007), in a study on the importance of morality in the positive evaluation of the ingroup, indicate that participants attributed, to a greater extent, values linked to morality to the ingroup than to the outgroup. These authors claim that the attribution of values is linked to a more positive evaluation of the ingroup, overcoming, for example, stereotypes of competence and sociability as the most important characteristics for the positive evaluation of the ingroup.

In the same vein, Bain et al. (2009) evaluated, among other variables, the influence of values over the Chinese dehumanization by Australians. The results obtained by these authors show that the values can be used in a subtle way in the dehumanization of an outgroup, as higher allocation of values linked to human characteristics to Australians than to the Chinese were observed. These results corroborate the findings of Struch and Schwartz (1989) that values are important indicators of dehumanization and that the phenomenon of dehumanization is not restricted to allocation of emotions (Leyens, Demoulin, Vaes, Gaunt \& Paladino, 2007). However, Bain et al. (2009) draw attention to the fact that the desirable and positive nature of the 
values may limit their use to make negative attributions to an outgroup.

In this sense, the present study seeks to test if individuals perceive dissimilarities between the values attibuted to themselves, to white and black, and if these dissimilarities can follow a prejudiced logic, expressing subtle racial prejudice. Therefore, two studies have been developed. Study 1 aims to evaluate the perception of the valence of values. Although the values in nature have positive valence (Bain et al., 2009), we propose that they can be differentiated in terms of socio-economic progress based on the typology proposed by Inglehart (1977), like the progressive values of the first world and the traditional and less advanced values of third world (Camino et al., 2001). Study 2 seeks to test if the values that individuals attribute to themselves, blacks and whites, are different and if this difference follows a prejudiced logic, that is, that progressive values (first world) are attibuted to the white (or themselves) and more traditional values (third world) are attibuted to blacks.

\section{Study 1}

Inglehart (1977) states that the changes that the economy of the post-modern Western societies have undergone were related to modifications in the hierarchy of values. In other words, cultural change, through the emergence of new values, followed the changes in the production conditions of these societies. Thus, societies with basic social problems such as economic instability, give priority to materialistic values, while societies that have solved such problems give priority to post-materialistic values. Thus, Inglehart (1977) defines in his studies what are the values of advanced industrialized or developed countries (named as first world countries) and countries in process of industrialization or underdeveloped countries (named as third world countries). Although the division into first, second and third world has fallen into disuse, because it makes reference to an outdated geopolitical model, the first and third world terms are still commonly used to rate the development of countries and the strength of their economies (Lins, Lima-Nunes, \& Camino, 2014; Lima-Nunes \& Camino, 2011). In this work, the terms first and third world represent, respectively, the developed and underdeveloped countries, indicating the development of these in socioeconomic terms. In this sense, this study aims to evaluate the valence of values in terms of socio-economic progress, identifying those values that are representative of developed countries of the first world, and of underdeveloped countries of the third world.

\section{Method}

Participants. Take part in this study 220 students from a Brazilian public university, mostly women (67\%) with a mean age of 21 years $(S D=3.01)$.

Instruments. The Psychosocial Values Questionnaire (PVQ-24; Pereira et al., 2004) was used. This instrument consists of 24 values evenly distributed between systems and subsystems of values proposed by the societal approach of values: Post-materialistic system, composed of three subsystems, Social wellbeing (freedom, equality, fraternity and social justice), Professional well-being (professional achievement, hard work, responsibility and competence) and Individual well-being (joy, love, comfort and self-fulfillment); the Materialistic System (wealth, profit, status and authority); the Religious System (obedience to God's laws, religiosity, soul salvation and fear of God); and the Hedonistic System (pleasure, an exciting life, sexuality and sensuality). The PVQ has presented evidence of validity based on the internal structure and adequate internal consistency coefficients (Pereira et al., 2004).

The task of participants was to read the list of 24 values and then indicate the three values in order of importance, that they consider as values of the first world and of the third world. At the end of this task, participants answered some sociodemographic questions (age, sex, course, time of course, religion).

Procedure. The questionnaires were applied in the classroom and answered individually. Students were informed of the voluntary nature of their participation in the research, as well as were assured the anonymity of answers and respect for the ethical guidelines governing research with human beings. The average time of response was 10 minutes. This research project was approved by the Ethics and Research Committee of the Health Sciences Center of the Federal University of Paraíba, Protocol no 157/05.

Data analysis. In order to verify if there are differences between the values attibuted by students to developed (first world) and developing (third world) countries, a comparison of attibuted average ( $t$-test) was performed. Therefore, a weighted average was used in analyses. The value indicated as the first more important got 3 points, the second most important got 2 points, and the third most important got 1 point. Subsequently, new variables were created and the score 
of the values were grouped according to the systems they are part. For example, if the student indicated the following order $1^{\circ}=$ Love, $2^{\circ}=$ Freedom and $3^{\circ}=$ Profit, the system of "individual well-being" would get 3 points, the "social well-being", 2 points, and "materialism", 1 point. To evaluate the effect size, $d$ Cohen was used, with values between 0.20 and 0.50 indicating small effects, values between 0.50 and 0.80 indicating intermediate effects and values above 0.80 indicating large effects (Cohen, 1988).

\section{Results}

The results indicated that, to first world countries, students attibuted values related to individual wellbeing, $t(219)=4.47, p<.001, d=0.30,95 \%$ CI [0.17, $0.43]$ and materialistic, $t(219)=11.12, p<.001 d=$ $0.75,95 \%$ CI $[0.59,0.89]$ systems. In turn, values of social well-being, $t(219)=9.26, p<.001 d=0.62,95 \%$ CI $[0.48,0.77]$, professional well-being, $t(219)=2.84, p$ $=.005 d=0.19,95 \%$ CI [0.06, 0.32], hedonists, $t(219)$ $=3.91, p<.001 d=0.26,95 \%$ CI $[0.13, .40]$ and religious, $t(219)=7.26, p<.001 d=0.49,95 \%$ CI [0.34, 0.63 ] were attibuted to countries of the third world. These results are shown in Table 1.

Noting the means allocated to the countries of first and third world, it is observed that materialistic values are considered the most important to describe the first world, and the values of social well-being to characterize the third world. On the second level are the values of individual and professional well-being, to indicate the countries of first and third world, respectively. Finally, the lesser relevance of the hedonists and religious values attibuted to third world countries.

\section{Discussion}

According to the study of Inglehart (1977), it was expected that post-materialistic values would be attibuted to first world countries, while materialistic, hedonistic and religious values would be attibuted to third world countries. However, the results indicated that participants attibuted materialistic and post-materialistic values of individual and professional well-being (although for the latter the average allocation to the third world was greater) to the first world while to the third world they attributed the post-materialistic values of social and professional well-being and religious and hedonistic values. It is observed that the system of individual well-being was regarded as typical of first world countries, and religious and hedonistic systems of third world countries, supporting the theory of Inglehart (1977). However, the classification made by the participants regarding the values of social, professional and materialistic well-being differed from the proposed by Inglehart (1977).

In short, the results show that values related to merit and personal achievements (materialism, individual well-being, also considering the professional well-being) are attibuted to the first world, while values related to community and social norms (social wellbeing and religion) are attibuted to the third world. This classification is close to that proposed by Hofstede (1980), between individualist and collectivist values. Collectivist cultures are characterized by a way of life more centered on society, whereas in individualist cultures the emphasis is on the individual. In addition, the societies of the first world (developed countries: Europe and North America) have more individualistic features, while the third world (developing countries:

Table 1

Average scores of values attibuted to the first and third world countries

\begin{tabular}{|c|c|c|c|c|c|c|c|}
\hline \multirow{2}{*}{ Values } & \multicolumn{2}{|c|}{ Attribution } & \multirow{2}{*}{$t(219)$} & \multirow{2}{*}{$p$} & \multirow{2}{*}{ Cohen's $d$} & \multicolumn{2}{|c|}{$95 \% \mathrm{CI}$} \\
\hline & First world & Third World & & & & Lower & Upper \\
\hline Social well-being $^{1}$ & 0.32 & 1.66 & 9.26 & .001 & 0.62 & 0.48 & 0.77 \\
\hline Individual well-being $^{1}$ & 1.19 & 0.59 & 4.47 & .001 & 0.30 & 0.17 & 0.43 \\
\hline Professional well-being ${ }^{1}$ & 1.04 & 1.46 & 2.84 & .005 & 0.19 & 0.06 & 0.32 \\
\hline Materialism & 3.18 & 1.05 & 11.12 & .001 & 0.75 & 0.59 & 0.89 \\
\hline Hedonism & 0.18 & 0.59 & 3.91 & .001 & 0.26 & 0.13 & 0.40 \\
\hline Religiosity & 0.10 & 0.73 & 7.26 & .001 & 0.49 & 0.34 & 0.63 \\
\hline
\end{tabular}

Note: 1 . These values make up the post-materialistic system; The values in bold indicate the highest average among groups. 
Latin America, Africa and parts of Asia) have more collectivist features (Hofstede, 2003; Minkov, 2012).

On the other hand, the difference between the results from the present study and those from Inglehart in the attribution of values to the first and third world can be a reflection of the "place" of the person who attributes the values. Inglehart (1991) states that the citizens of the first world would adhere more strongly to post-materialistic values than citizens of the third world, who would adhere to materialistic values, but Inglehart does not analyze how these citizens perceive themselves or are perceived by others. That is to say, the attributions of values may differ depending on the position that the evaluator has (e.g., ingroup or outgroup).

\section{Study 2}

Study 2 aims to test the hypothesis that the values attibuted to blacks and whites are different and if this difference follows a prejudice-based logic, where progressive and individualistic values of the first world are attibuted to the white (individual well-being and materialism) and more traditional and collectivist values of the third world (social well-being, hedonism and religiosity) are attibuted to blacks. According Camino et al. (2001), white people would be associated with progressive values of the first world and black people with traditional and less advanced values of the third world. Thus, black people will be characterized as more linked to thirdworld values and to natural aptitudes linked to sport or art (show), while white people will be perceived as having skills for intellectual activities (qualified) or activities connected to power. In addition, this study test whether there are differences between the values that individuals attribute to themselves and the values they attribute to white and black Brazilians. The proposed hypothesis is that people will see less difference between their values and those of white Brazilians and great difference between their values and those of black Brazilians.

\section{Method}

Participants and design. Take part in this study 420 public university students, mostly female $(67.2 \%)$ with mean age of 23 years $(S D=5)$. Most students self-reported to have brown skin (56.4\%) and white skin $(44.6 \%)$. Participants who identified themselves as blacks $(n=6)$ were not included in the final sample because the goal is to study prejudice against blacks, and then, it is not of interest to study the group that suffers the prejudice. Participants were randomly attibuted to one of two conditions (black target $v$ s. white target) on a between subjects design.

Procedure. The task of participants was to read a list of 24 values of PVQ-24 and later indicate, in order of importance, what were the three most important values in their lives. Then, participants were asked to indicate, also in order of importance, the three values that white or black (depending on the experimental condition) Brazilians consider most important to their lives. Participants were informed of the voluntary nature of their participation in the research, as well as were assured on anonymity of answers and respect for the ethical guidelines governing research with human beings. The average time of response was 15 minutes.

Data analysis. Comparisons of means were performed ( $t$-test) to check whether there are differences between: (1) the values attibuted by the students to themselves and to the blacks, (2) to themselves and to the white, (3) and between whites and blacks. The same criteria of weighting to values in Study 1 was used here. To evaluate the effect size, $d$ Cohen was used, with values between 0.20 and 0.50 indicating small effects, values between 0.50 and 0.80 indicating intermediate effects and values above 0.80 indicating large effects (Cohen, 1988).

\section{Results}

Comparing participants' attribution of values to themselves with the values attibuted to white Brazilians, it is observed that students apply themselves more often values of social well-being, $t(199)=8.05, p<.001, d=$ $0.57,95 \%$ CI [0.42, 0.72], individual well-being, $t$ (199) $=6.82, p<.001, d=0.48,95 \%$ CI $[0.35,0.63]$ and religiosity, $t(199)=6.56, p<.001, d=0.46,95 \% \mathrm{CI}$ $[0.32,0.60]$. On the other hand, they attribute to the white population more often values of materialism, $t$ $(199)=14.54, p<.001, d=1.03,95 \%$ CI $[0.85,1.20]$ and hedonism, $t(199)=5.13, p<.001, d=0.36,95 \%$ CI $[0.21,0.50]$. Regarding the allocation of values to black Brazilians and to themselves, students apply more often professional well-being, $t(219)=5.45, p<.001$, $d=0.37,95 \%$ CI $[0.23,0.37]$, individual well-being, $t$ $(219)=9.17, p<.001, d=0.62,95 \%$ CI $[0.47,0.62]$, and religiosity, $t(219)=7.16, p<.001, d=0.48,95 \% \mathrm{CI}$ $[0.62,0.48]$, values to themselves, while they attribute greater adherence to values of social well-being, $t$ (219) $=16.26, p<.001, d=1.10,95 \%$ CI $[0.93,1.10]$, to the black population. The results are shown in Table 2. 
When comparing values attibuted to black and white, it is observed that participants apply greater adherence to values of social well-being to blacks than to whites, $t(418)=23.34, p<.001, d=1.14,95 \% \mathrm{CI}$ $[1.02,1.26]$. On the other hand, they attribute to the white people greater adherence to the values of individual well-being, $t(218)=2.83, p<.01, d=0.14,95 \%$ CI [0.04, 0.23], professional well-being, $t(218)=2.67, p$ $<.01, d=0.13,95 \%$ CI [0.03, 0.22], materialistic values, $t(218)=13.51, p<.001, d=0.66,95 \%$ CI $[0.55,0.76]$, hedonistic values, $t(218)=4.25, p<.001, d=0.21$, $95 \%$ CI $[0.11,0.30]$, and religious values, $t(218)=3.47$, $p<.001, d=0.17,95 \%$ CI $[0.00,0.26]$. The results are shown in Table 3.

\section{Discussion}

The results of this study allow us to accept part of the proposed hypotheses. As can be seen in Table 2, the values that individuals attribute to themselves differ significantly from those that they attribute to blacks, as posed in the hypothesis; although differences in relation to whites were also observed. Participants attributed, to a greater extent, values of social well-being to the black, while they attach to themselves the values of individual well-being, as well as professional and religious values. The attribution of materialistic and hedonistic values (with more individual focus) to themselves and to the black was low and did not differ between them. Compared with whites, people attribute more postmaterialistic values and religious values to themselves, while they attribute more individualistic values, like materialistic and hedonistic values, to whites.

Comparing the attribution of values to white and black people, shown in Table 3, the values attibuted to a greater extent to the blacks were the social well-being, of collectivist nature, as observed in Study 1. These values would be more representative of the cultures of third world or developing countries, like Latin America and Africa (Hofstede, 2003; Minkov, 2012). Among the values attibuted to a greater degree to whites are those characterized in Study 1 as the first world values or from developed countries, which are more individualistic, like the individual well-being, professional well-being and materialism.

Also worthy of attention is the fact that participants have attibuted to themselves and to the white greater adherence to religious values compared to blacks, bearing in mind that the african-Brazilian religions are seen as typical of the black population in

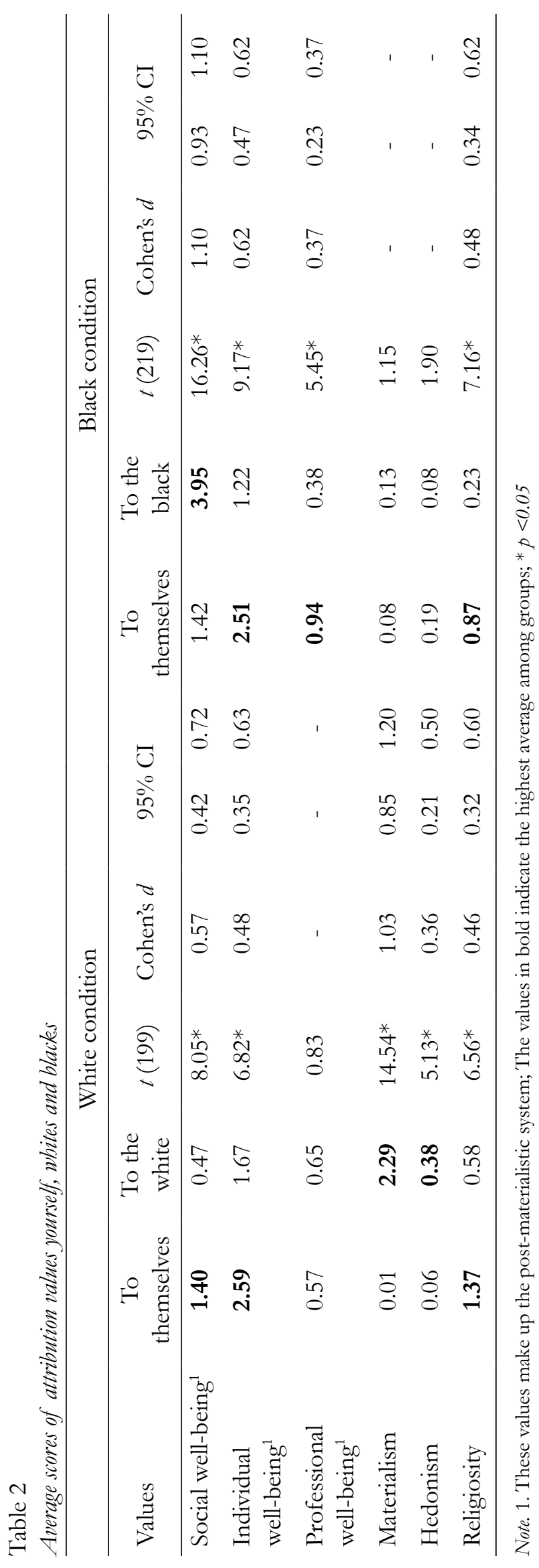


Table 3

Average scores of values attibuted to white and black.

\begin{tabular}{|c|c|c|c|c|c|c|c|}
\hline \multirow{2}{*}{ Values } & \multicolumn{2}{|c|}{ Attribution } & \multirow{2}{*}{$t(418)$} & \multirow{2}{*}{$p$} & \multirow{2}{*}{$\begin{array}{c}\text { Cohen's } \\
d\end{array}$} & \multicolumn{2}{|c|}{$95 \% \mathrm{CI}$} \\
\hline & To the black & To the white & & & & Lower & Upper \\
\hline Social well-being ${ }^{1}$ & 3.95 & 0.47 & 23.34 & .001 & 1.14 & 1.02 & 1.26 \\
\hline Individual well-being ${ }^{1}$ & 1.22 & 1.67 & 2.83 & .005 & 0.14 & 0.04 & 0.23 \\
\hline Professional well-being ${ }^{1}$ & 0.38 & 0.65 & 2.67 & .008 & 0.13 & 0.03 & 0.22 \\
\hline Materialism & 0.13 & 2.29 & 13.51 & .001 & 0.66 & 0.55 & 0.76 \\
\hline Hedonism & 0.08 & 0.38 & 4.25 & .001 & 0.21 & 0.11 & 0.30 \\
\hline Religiosity & 0.23 & 0.58 & 3.47 & .001 & 0.17 & 0.00 & 0.26 \\
\hline
\end{tabular}

Note. 1 . These values make up the post-materialistic system; The values in bold indicate the highest average among groups.

Brazil (Camino et al., 2001). It is possible that this result is explained by the fact that the values that make up the Religious system PVQ-24 (obedience to God's laws, fear of God, religiosity and soul salvation) are more related to religious values of Christianity than to the religions of African origin commonly related to the black community, constituting a possible limitation of this instrument.

\section{General discussion}

The studies developed here analysed whether individuals perceive dissimilarities between the values attibuted to themselves, to white and to the black, and if these dissimilarities follow a prejudiced logic, expressing subtle racism. It must be noted that this study used the societal approach of values (Pereira et al. 2004) whose development is based on psychological links between different levels of the analysis proposed by Doise (1982). Thus, this research took into account that both the individual needs and priorities of individuals are also social constructions.

The main findings of this study indicated a perception of differences between the values attibuted as important for blacks and whites. In fact, the perception of dissimilarity between the values of social groups is a factor that influences prejudicial attitudes (Brandt \& Van Tongeren, 2015; Guan et al., 2011; Maxwell-Smith, Seligman, Conway, \& Cheung, 2015). Furthermore, the perceived differences between the values of the ingroup and the outgroup are related to a more negative perception and dehumanization of the outgroup, while the perception of similarity is related to reduced hostility (Greenhalgh \& Watt, 2015). According to Greenhalgh and Watt (2015), the perceived differences between the values of the ingroup and the outgroup can lead to a perception of threat to the ingroup rules and lifestyles, since the values are an important part of the structure and ingroup identity.

In this sense, it is possible that prejudice is linked to the perception of differences in values between groups or cultures (Greenhalgh \& Watt, 2015; Ramsay et al., 2013). Therefore, the initial premise of this study was that the skin color has an influence, in a sense, on the association with the systems of values. In the case of the white, they would be associated with progressive values of the first world (freedom, equality, fraternity, social justice), and in the case of the black, they would be associated with traditional values, typical of the third world (materialistic, hedonistic and religious values). It is important to highlight that the goal here was not to attribute a negative or positive character to values, as in the societal approach values are designed as ideologies about how society should be organized, with possibility of organizing them hierarchically, for example, in function of socio-economic progress.

Some studies by Camino et al. (2001, Camino, Silva, Machado, \& Mendoza, 2007), in which the participants had the task to attribute adjectives of people living in first world countries (ambitious, independent, civilized and rich) and third world (poor, solidarity, worker and dreamer) for black and white people. These studies showed that traces of third world countries were attibuted to black people, and first world's features, to white people. In this sense, the results obtained in this study were similar, although the task of the participants was to indicate which values Brazilian blacks and whites consider most important to their lives.

Regarding the first study, results did not confirm the assumptions of Inglehart, with respect to the belief 
that the third world countries would be characterized by materialistic, hedonistic and religious values, and the first world countries, by values of social, individual and professional well-being. Nevertheless, the logic used by participants for classification was that the first world countries would be characterized by more individualistic values (individual well-being, professional well-being and materialism) while third world countries would be characterized by more collectivist values (social well-being, religiosity), corroborating the distinction between cultural individualism/collectivism of the Hofstede model (Hofstede, 2003; Minkov, 2012).

The results seem to show some contradictions regarding student's perception about black population. First, while they attach to themselves the values of individual well-being primarily, they attach almost exclusively values of social well-being to the black population. These results can be interpreted in the light of the current socio-political context. The appreciation of social justice would be linked both to the awareness of strong social discrimination practiced in Brazil and to the increasing claims of the black population.

The results of this study contradict what Inglehart (1991) says when he ensures that third world countries would show higher adherence to the values related to needs not yet found, such as materialistic and hedonistic values, and that, when they met the requirements, they would value the post-materialistic system of values. However, the Brazilian university students, of third-world, attributed the post-materialistic values of social, individual and professional well-being as the most important values for themselves. However, these results can be justified by the level of education of the participants, as were they were university students and, according to Vala (1994), the educational level is the best predictor of adherence to post-materialistic values. It is again noteworthy that the allocation of what would be values "typical" of first and third world countries is intrinsically related to the allegiance of who attributes the value, possibly first world people attibuted other values to underdeveloped or third world countries.

In addition, the new economic and cultural changes at the global level, and the new tone that has been given to some countries before categorized as third world countries, and today named as emerging due to the economic position they are achieving, such as the BRICs (Brazil, Russia, India and China), calls for a reflection on what are countries of first and third world and if the students of the research believe that they are living in a third world country. The definition adopted in this study of first and third world is not restricted to a specific technique but to the concept of common sense of the characteristics that these countries have. However, participants were not asked how they would classify their country. This could be assessed in future studies, taking into account that the attribution of values may differ depending on the position that the evaluator has.

Along with the perceptions of the values of social groups, the structure of values of each individual is an important factor in attitudes and behavior towards outgroups. Participants attributed post-materialistic values as the most important values for themselves, even though Brazil is a country where social, political and basic economic problems have not been solved. As an example of this, we can mention the demonstrations that took place in the country in 2013. In other words, Brazil is still classified as a developing country and, therefore, materialistic values are widely shared. However, this does not negate the possibility of adherence to post-materialistic values, and even so would have materialistic values reduced importance (Pereira \& Camino, 1999). Thus, participants may consider both post-materialistic and materialistic values equally important, not necessarily coming into contradiction.

According to Billig (1985), it is natural to observe in today's society both universalist and globalizing aspirations, as nationalist aspirations (sectorial) motivated by competition and meritocracy, typical of capitalism. That is, both moral aspirations of freedom, fraternity and equality, and concerns regarding the practical application of justice in the world are together in the same society.

According to Billig (1991), these contradictions result in a paradox. Then, the more the bias is criticized, the more prejudices coming from liberalism are justified, and the self-defense of anti-racist rules could result in justification of the own prejudice. In this sense, the postmodern social reality highlights "both the centrality of post-materialistic values to the sound development of society as well as, increasingly, becomes subject to the laws of the global market, aiming at profit and economic accumulation typical of materialism" (Pereira et al., 2005, p.23).

This study also confirms the results of previous studies (Lima, 1997; Pereira Lima, \& Camino, 1997) demonstrating the importance and influence of the content of the religious system in students' lives because, as noted, students attibuted greater adherence to the values of the religious system to themselves compared, in general, to white and black Brazilians. 


\section{Final considerations}

The results obtained in this research infer that there are differences in attribution that participants make to themselves, to black and to white Brazilians. In general, participants adhere more to religious values and values of individual and professional well-being, while they attribute individualistic values to the white, and collectivist values to the black. Although the results presented here are consistent with the literature, some limitations were identified. The sample used in this study is composed entirely of students with high education level, which may explain, for example, the preference for postmaterialist values. In this regard, future studies could test the objectives proposed here with samples of the general population, which might lead to different results than those observed here. Another limitation concerns the content of the religious system in PVQ that refers to religious values of Christianity, excluding other aspects of the religions of African origin. Future studies may broaden the content of the items of this system by adding items that cover other aspects of religiosity. It is important to note that the content of the items may vary depending on the cultural context and can be adapted to different cultures without detriment to the religious value system.

Another possible limitation is related to the fact that the skin color of participants were not controlled, neither in data collection nor in the analysis. However, the studies were conducted in contexts where white and brown skin color predominated and the participants were randomly allocated to the experimental conditions, what can control possible differences of judgments made by participants from minority groups. Lastly, although the results obtained indicate that participants perceive dissimilarities between the values that are most important to blacks and whites, we did not test directly whether this perception of dissimilarity leads to prejudice-based attitudes. Future studies may assess whether, in the Brazilian context, which is marked by a more subtle form of racism, this perception of dissimilarities between the values is related to racial discrimination, as has been reported in the literature, in the context of other studies (Brandt \& Van Tongeren, 2015; Greenhalgh \& Watt, 2015).

In general, this research contributes to understanding the relationship between racial prejudice and the allocation of social values, as it addressed two topics directly related to the attitudes and behaviors of individuals who can make use of representational repertoires, such as the perception of similarities and dissimilarities between the values of social groups, to justify, in a subtle way, their prejudiced actions.

\section{References}

Allport, G. (1954). The nature of prejudice. Cambridge: Addison-Wesley.

Bain, P., Park, J., Wkok, C., \& Haslam, N. (2009). Attributing human uniqueness and human nature to cultural groups: Distinct forms of subtle dehumanization. Group Processes \& Intergroup Relations, 12(6), 789-805. doi: 10.1177/1368430209340415

Biernat, M., \& Vescio, T. K. (2004). Values and prejudice. In C. S. Crandall \& M. Schaller (Eds.), Social Psychology of Prejudice: Historical and Contemporary Issues (pp. 191-216). Lawrence: Lewinian Press.

Billig, M. (1985). Prejudice, categorization and particularization: From a perceptual to a rhetorical approach. European Journal of Social Psychology, 15 (1), 79-103. doi: 10.1002/ ejsp.2420150107

Billig, M. (1991). Ideology and opinions: Studies in rhetorical psychology. London: Sage.

Brandt, M. J., \& Van Tongeren, D. R. (2015). People both high and low on religious fundamentalism are prejudiced toward dissimilar groups. Journal of Personality and Social Psychology. Publicação online avançada. doi: 10.1037/pspp0000076

Camino, L., Silva, P., Machado, A., \& Mendoza, R. (2007). El prejuicio racial en Brasil: Sus formas encubiertas de expresión. In J. Gissi \& D. Sirlopú (Eds.). Asedios a la psique latino-americana. Aportes desde la Psicología política, Psicología comunitaria y Psicología social. (pp. 183-204). Santiago de Chile: Pontifica Universidad Católica de Chile.

Camino, L., Silva, P., Machado, A., \& Pereira, C. (2001). A face oculta do racismo no Brasil: Uma análise psicossociológica. Revista de Psicologia Política, 1(1), 13-36.

Cohen, J. (1988). Statistical power analysis for the Behavioral sciences. New York: LEA Publishers.

Doise, W. (1982). L.explication en psychologie sociale. Paris: PUF.

Esses, V. M., Veenvliet, S., Hodson, G., \& Mihic, L. (2008). Justice, morality, and the dehumanization 
of refugees. Social Justice Research, 21, 4-25. doi: 10.1007/s11211-007-0058-4

Estramiana, J. L. A., Pereira, C. R., Monter, M. R., \& Zlobina, A. (2014). Valores sociais. In L. Camino, A. Torres, M. Lima, \& M. Pereira (Eds.), Psicologia Social (pp. 309-354). Brasília: TechnoPolitik.

Fernandes, S., Costa, J., Camino, L., \& Mendoza, R. (2007). Valores psicossociais e orientação à dominância social: Um estudo acerca do preconceito. Psicologia: Reflexão e Crítica, 20, 490-498.

Gaertner, S. L., \& Dovidio, J. F. (1986). The aversive form of racism. In J. F. Dovidio \& S. L. Gaertner (Eds.), Prejudice, discrimination, and racism (pp. 61-89). San Diego: Academic Press.

Gouveia, V. V., Milfont, T. L., \& Guerra, V. M. (2014). Functional theory of human values: Testing its content and structure hypotheses. Personality and Individual Differences, 60, 41-47. doi: 10.1016/j. paid.2013.12.012

Greenhalgh, E. M., \& Watt, S. E. (2015). Preference for consistency and value dissimilarities in dehumanization and prejudice toward asylum seekers in Australia. European Journal of Social Psychology, 45, 110-119. doi: 10.1002/ ejsp.2066

Guan, Y., Verkuyten, M., Fund, H. H., Bond, M. H., Chen, S. X., \& Chan, C. C. (2011). Out-group value incongruence and intergroup attitude: The roles of common identity and multiculturalism. International Journal of Intercultural Relations, 35(3), 337-385. doi: 10.1016/j.ijintrel.2010.04.007

Hofstede, G. (1980). Culture's consequences: International differences in work-related values. Beverly Hills: Sage Publications.

Hofstede, G. (2003). Culture's consequences: comparing values, behaviors, institutions and organizations across nations. Beverly Hills: Sage Publications.

Inglehart, R. (1977). The silent revolution. Princeton: Princeton University.

Inglehart, R. (1991). El cambio cultural en las sociedades industriales avanzadas. Madrid: Siglo XXI.

Katz, I., \& Hass, R. (1988). Racial ambivalence and American value conflict: Correlacional and priming studies of dual cognitive structures. Journal of Personality and Social Psychology, 55(6), 893-905. doi:10.1037/0022-3514.55.6.893
Kinder, D., \& Sears, D. (1981). Prejudice and politics: Symbolic racism versus racial threats to good life. Journal of Personality and Social Psychology, 40 (3), 414 431. doi: 10.1037/0022-3514.40.3.414

Leach, C. W., Ellemers, N., \& Barreto, M. (2007). Group virtue: The importance of morality (vs. Competence and Sociability) in the positive evaluation of in-groups. Journal of Personality and Social Psychology, 93(2), 234-249. doi: 1037/0022-3514.93.2.234

Leyens, J. P., Demoulin, S., Vaes, J., Gaunt, R., \& Paladino, M. P. (2007). Infra-humanization: The wall of group differences. Social Issues and Policy Review, 1(1), 139-172. doi: 10.1111/j.1751-2409.2007.00006.x

Lima, M. (1997). Valores, participação política, atitudes face a democracia e ao autoritarismo: uma análise da socialização política dos universitários da Paraíba. (Dissertação de mestrado). Universidade Federal da Paraíba, João Pessoa.

Lima-Nunes, A., \& Camino, L. (2011). Atitude político -ideológica e inserção social: Fatores psicossociais do preconceito racial? Psicologia \& Sociedade, 23, 135-143. doi: 10.1590/S0102-71822011000100015

Lins, S. L. B., Lima-Nunes, A., \& Camino, L. (2014). O papel dos valores sociais e variáveis psicossociais no preconceito racial brasileiro. Psicologia \& Sociedade, 26, 95-105. doi: 10.1590/ S0102-71822014000100011

Maxwell-Smith, M. A., Seligman, C., Conway, P., \& Cheung, I. (2015). Individual differences in commitment to value-based beliefs and the amplification of perceived belief dissimilarity effects. Journal of Personality, 83(2), 127-141. doi: 10.1111/ jopy.12089

McConahay, J. (1986). Modern racism, ambivalence and the modern racism scale. In J. Dovidio \& S. Gaertner (Eds.), Prejudice, discrimination and racism (pp. 91-126). New York: Academic Press.

McDonald, R. I., \& Crandall, C. S. (2015). Social norms and social influence. Current Opinion in Behavioral Sciences, 3, 147-151. doi: 10.1016/j. cobeha.2015.04.006

Minkov, M. (2012). Cross-cultural analysis: The science and art of comparing the world's modern societies and their cultures. Beverly Hills: Sage Publications.

Pereira, C., \& Camino, L. (1999). Proposta de um modelo psicossociológico para o estudo das atitudes 
políticas de estudantes universitários. In M. Souza (Eds.), Iniciados (pp. 427-440), João Pessoa: Editora Universitária.

Pereira, C., Camino, L., \& Costa, J. (2004). Análise fatorial confirmatória do Questionário de Valores Psicossociais - QVP24. Estudos de Psicologia, 9(3), 505-512.

Pereira, C., Camino, L., \& Costa, J. (2005). Um estudo sobre a integração dos níveis de análise dos sistemas de valores. Psicologia: Reflexão e Crítica, 18(1), $16-25$

Pereira, C., Lima, M., \& Camino, L. (1997). A prática política: uma análise psicossociológica em termos de valores e inserção social. In M. Silva (Eds.), Iniciados (pp. 199-235). João Pessoa: Editora Universitária.

Pettigrew, T., \& Meertens, R. (1995). Subtle and blatant prejudice in Western Europe. European Journal of Social Psychology, 25 (1), 57-75. doi: 10.1002/ ejsp.2420250106

Ramsay, J. E., Pang, J. S., Shen, M. J., \& Rowatt, W. C. (2013). Rethinking value violation: Priming religion increases prejudice in Singaporean Christians and Buddhists. The International Journal for the Psychology of Religion, 24(1), 1-15. doi: 10.1080/10508619.2012.761525

Rokeach, M. (1968). Beliefs, attitudes and values: $A$ theory of organization and change. San Francisco: Jossey-Bass.

Rokeach, M. (1973). The nature of human values. New York: Free Press.

Schwartz, S. (1992). Universals in the content and structure of values: Theoretical advanced and empirical testes in 20 countries. In M. Zanna (Eds.), Advances in experimental social psychology. (vol. 25, pp. 1-65). Orlando: Academic Press.

Schwartz, S. H. (2006). A theory of cultural value orientations: Explication and applications. Comparative Sociology, 5, 136-182. doi: 10.1163/156913306778667357

Schwartz, S. H., Cieciuch, J., Vecchionem M., Davidov, E., Fischer, R., Beierlein, C., et al. (2012). Refining the theory of basic individual values. Personality processes and individual differences, 103, 663-668. doi: $10.1037 / \mathrm{a} 0029393$

Sears, D. O., \& Kinder, D. R. (1971). Racial tensions and voting in Los Angeles. In W. Z. Hirsch (Ed.), Los Angeles: Viability and prospects for metropolitan leadership (pp. 51-88). New York: Praeger.

Struch, N., \& Schwartz, S. H. (1989). Intergroup aggression: Its predictors and distinctness from in-group bias. Journal of Personality and Social Psychology, 56(3), 364-373. doi: 10.1037/0022-3514.56.3.364

Tajfel, H. (1982). Social psychology of intergroup relations. Annual Review of Psychology, 33(1), 1-39.

Vala, J. (1994). La emergencia de los valores post-materialistas en Portugal. In J. Nícolas, \& R. Inglehart (Eds.), Tendencias mundiales de cambio en los valores sociales y politicos (pp. 157-170). Madrid: Fundesco.

Recebido em: 02/02/2016

Reformulado em: 04/04/2016; 15/04/2016

Aceito em: 02/05/2016 
Nota dos autores:

Agradecimentos: Essa pesquisa foi financiada pelo CNPq no âmbito da bolsa de mestrado atribuída ao primeiro autor.

Sobre os autores:

Samuel Lincoln Bezerra Lins é mestre em Psicologia Social (Universidade Federal da Paraíba) e doutor em Psicologia (Universidade do Porto, Portugal). Atualmente é professor da Faculdade de Psicologia e de Ciências da Educação da Universidade do Porto (Portugal), e pesquisador do Laboratório de Psicologia Social (LPS) vinculado ao Centro de Psicologia da Universidade do Porto (CPUP).

E-mail: samuellins@fpce.up.pt

Tiago Jessé Souza de Lima é doutor em Psicologia Social pela Universidade Federal da Paraíba, com estágio no Instituto de Ciências Sociais da Universidade de Lisboa, Portugal. Atualmente é docente da graduação em Psicologia da Universidade de Fortaleza (UNIFOR) e do Mestrado Profissional em Administração (UNIFOR). É membro do Grupo de Pesquisa em Comportamento Político (GPCP - UFPB) e do Laboratório de Estudos sobre Processos de Exclusão Social (LEPES - UNIFOR).

E-mail: tiago.souzalima@hotmail.com

Luana Elayne Cunha de Souza é doutora em Psicologia Social pela Universidade Federal da Paraíba, docente na graduação e pós-graduação em Psicologia da Universidade de Fortaleza (UNIFOR), Fortaleza - CE, onde coordena o Laboratório de Estudos sobre Processos de Exclusão Social (LEPES).

E-mail:luana_elayne@hotmail.com

Aline Lima-Nunes é doutora em Psicologia com especialidade em Psicologia Social pelo Instituto Universitário de Lisboa (ISCTE-IUL/Portugal). Professora Adjunta da Universidade Federal de Campina Grande (UFCG). Pesquisadora na área de Psicologia Social da Justiça e Processos de Exclusão Social. É membro do Grupo de Pesquisa em Cultura e Processos Psicossociais (UFCG).

E-mail: limanunes.aline@gmail.com

Leoncio Camino é doutorado e pós-doutorado em Psicologia Social pela Université Catholique de Louvain, Bélgica, professor Emérito da Universidade Federal da Paraíba, João Pessoa-PB e coordenador do Grupo de Pesquisa em Comportamento Político (GPCP).

E-mail: leocamino@uol.com.br

Contato com os autores:

Faculdade de Psicologia e de Ciências da Educação da Universidade do Porto

Rua Alfredo Allen, 4200-135

Porto, Portugal

Email: samuellins@fpce.up.pt

Psico-USF, Bragança Paulista, v. 22, n. 2, p. 309-321, mai./ago. 2017 
